\title{
Sürdürülebilir Destinasyon Yaratma Sürecinde Örgütlenmenin Önemi: Çanakkale Turizmi Üzerine Bir Araştırma*
}

The Importance of Organization in the Process of Creating Sustainable Destination: A Research on the Tourism of Çanakkale

\author{
Koray GENÇ*, Lütfi ATAY**, Mustafa Yunus ERYAMAN*** \\ *Ö̆̆r. Gör., T. C. Abant İzzet Baysal Üniversitesi, Mudurnu Süreyya Astarcı Meslek Yüksekokulu, 14800, Bolu. \\ E-posta: koray.genc@yahoo.com \\ **Yrd. Doç. Dr., T.C. Çanakkale Onsekiz Mart Üniversitesi, Turizm Fakültesi, 17000, Çanakkale. \\ E-posta: lutfiatay@yahoo.com \\ ***Doç. Dr., T.C. Çanakkale Onsekiz Mart Üniversitesi, Ĕ̆itim Fakültesi, 17000, Çanakkale. \\ E-posta:yunuseryaman@gmail.com
}

\section{MAKALE BILGILERI}

Makale işlem bilgileri:

Gönderilme tarihi: 9 Haziran 2013

Birinci değerlendirme:29 Temmuz 2013

İkinci değerlendirme: 13 Eylül 2013

Kabul: 18 Eylül 2013

Anahtar sözcükler:

Sürdürülebilir destinasyon,

Destinasyon örgütlenmesi,

Destinasyon yönetim örgütü,

Çanakkale.

\section{ARTICLE INFO}

Article history:

Submitted: 9 June 2013

Resubmitted: 29 July 2013

Resubmitted: 13 September 2013

Accepted: 18 September 2013

Key words:

Sustainable destination, Destination organization, Destination management organization, Çanakkale.

\section{ÖZ}

Bu çalışmada, sürdürülebilir bir turizm destinasyonu oluşturulması sürecinde önemli turizm ziyaretçi merkezlerinden biri olan Canakkale'de, turizmin mevcut durumunun ve sürdürülebilirliğinin tespit edilmesi amaçlanmıștır. Bu kapsamda Çanakkale'de turizmle ilișkili olduğu tespit edilen paydașlarla görüșülerek nitel bir araştırma yapılmıştır. Yapılan görüşmelerle paydaşların ildeki turizmin mevcut durumu hakkındaki görüşleri ve ilde sürdürülebilir destinasyon geliştirme bağlamında Çanakkale kent merkezinde oluşturulabilecek bir destinasyon yapısı ve örgütIenmesi hakkında paydaș görüșlerinin açığa çıkarılması ön görülmüștür. Araștırmada yarı yapılandırılmış anket formuyla görüşme tekniği uygulanmıştır. Ayrıca doküman analiziyle de araştırma desteklenmiştir. Araştırma kapsamında merkezi yönetim, yerel yönetim, özel sektör, sivil toplum kuruluşları ve diğer kategoriler altında toplam yirmi dört paydașla görüsülmüștür. Araștırma bulgularına göre genel görüș; Canakkale'nin turizm potansiyelinin yüksek olmasına rağmen, çeșitli nedenlerden dolayı Çanakkale turizminin istenilen düzeyde olmadığı şeklindedir. Bunun önemli nedenlerinden bir tanesinin örgütlenme eksikliği olduğu, araştırmaya katılan paydaşlarca ifade edilmektedir. İldeki paydașları bir araya getirecek bir destinasyon yönetim örgütü kurulması, merkezi yönetimin oluşacak örgüte liderlik ve finansal kaynak konusunda öncülük yapması gerektiği paydașlar arasında öne çıkan başka bir görüş olmuştur.

\section{Giriş}

Birleşmiş Milletler Dünya Turizm Örgütü verilerine göre, 2010 yılında 939 milyon kişinin seyahat

* Bu makale, Koray Genç'in Çanakkale Onsekiz Mart Üniversitesi Sosyal Bilimler Enstitüsü'nde yazılan "Sürdürülebilir Destinasyon Yaratma Sürecinde Örgütlenmenin Önemi: Çanakkale Turizmi Üzerine Bir Araştırma" başlıklı yüksek lisans tezinden üretilmiştir. ettiği açıklanmıştır. 2011 yılında \%4'lük bir artışla 980 milyon kişinin ve 2012 yılında da \%4'lük bir artışla 1 milyar 35 milyon kişinin turizm faaliyetine katıldığ 1 belirtilmiştir. Uzun vadeli tahminlerle 2010 ile 2030 yılları arasında her yıl yaklaşık 43 milyon yeni turistin olacağ milyar 800 milyon kişinin seyahat edeceği öngörülmektedir (http://media.unwto.org, 09.01.2013). 
Açıklanan verilere bakarak turizm sektörünün sürekli gelişen önemli bir sektör haline geldiğini söylemek mümkündür. Turizm sektörünün getirisinin bu kadar yüksek olmasına paralel olarak turizm pastasından pay almak isteyen birçok destinasyon bulunmaktadır. Rakip destinasyonlar arasında fark yaratmak ve daha çok turist çekmek isteyen destinasyonlar, sürdürülebilir turizm faaliyetlerine yönelmektedir. Bu durumda da destinasyon yönetimi önemli bir unsur olarak ortaya çımaktadır. İyi bir destinasyon yönetimi için turizmle ilgili tüm paydaşların örgütlenmesi gerekmektedir. Olalı (1990) bu durumu ahenkli çalışma olarak ifade etmekte ve turizmle uzak veya yakın ilişkisi olan bütün kuruluşların, kişilerin arasında koordinasyonun olması gerektiğini belirtmektedir. Çünkü ziyaretçi bir destinasyonu ziyareti sırasında tek bir unsurdan faydalanmaz, birleşik bir ürünle ilgilenir. Destinasyona gelen ziyaretçi otelde konaklama yapar, restoranda yemek yer, ulaşım araçlarını kullanır, alışveriş yapar, eğlence mekânlarına gider. Bu nedenden dolayı gelen ziyaretçilerin memnuniyetinin sağlanmasında herkese sorumluluklar düşmektedir.

Günümüzde Barselona, Londra, Paris, Viyana gibi birçok başarılı destinasyonun paydaş örgütlenmesi ve yönetiminin öneminin farkına vararak ülkelerinin turizm yönetimi dışında yerel bazda destinasyon yönetim örgütleri oluşturdukları ve bu doğrultuda yaptıkları çalışmalarla başarılı oldukları söylenebilir. Türkiye'de de destinasyon yönetim örgütlenmesi konusunun öneminin farkına varılmakla beraber henüz somut adımlar atılamadığı ortadadır.

Bu çalışmada, sürdürülebilir destinasyon konusunun önemine değinilmekte ve yoğun bir iç turizm talebi olan Çanakkale'nin, sürdürülebilir destinasyon olabilmesi için gerek duyulan destinasyon örgütlenmesi değerlendirilmektedir. $\mathrm{Bu}$ nedenle; konuya ilişkin alanyazın taraması yapıldiktan sonra paydaşlarla yapılan görüşmelerden elde edilen ham veriler içerik analizine tabi tutulmuştur.

\section{SÜRDÜRÜLEBILLIR DESTINASYON}

Destinasyon kavramı üzerine alanyazında birçok tanım bulunmaktadır. Kısaca destinasyon; "gidilecek yer" anlamı taşımaktadır (Atay ve Akyurt 2007). Daha kapsamlı bir tanımda ise destinasyon; "sahip olduğu çeşitli turizm kaynakları ile turistleri çeken ve yoğun olarak turist ziyaretine ev sahipliği yapan, pek çok kurum ve kuruluşun sağladığı doğrudan veya dolaylı turizm hareketlerinin bütününden oluşan karmaşık bir ürün" olarak açıklanmıştır (Özdemir 2008). Coltman (1989) ise destinasyonu, yerel olmayan turist veya günübirlikçilerin hizmetine sunulmuş farklı doğal güzellikleri, özellikleri ve çekicilikleri olan bir alan olarak ifade etmektedir. Ziyaretçi perspektifinden bakıldığında ise destinasyon; büyük ölçüde benzer olanaklar sunan, bir dizi rakip alternatifleri arasından seçilecek herhangi bir turizm ürünü olarak görülmektedir (Laws 2002).

Turizmin günümüzde kitlesel hale gelmesiyle beraber birbiriyle rekabet etme durumunda olan bir çok destinasyon ortaya çıkmıştır. Rakipleri karşısında ön plana çıkmayı ve daha fazla turist çekmeyi amaçlayan destinasyonlar içinde sürdürülebilirliği sağlamak önemli bir unsur olarak gözükmektedir. İçöz vd. (2009) turizm hareketlerinin destinasyona birçok faydasının yanında ekonomik, kültürel, toplumsal ve çevresel zararlarının da olduğunu ifade etmektedirler. Bundan dolayıdır ki destinasyonda turizmin gelişiminin fayda ve maliyet ilişkisi yönüyle ele alınması daha doğru olacaktır. Ancak bu şekilde sürdürülebilir destinasyon oluşturulabilir.

Sürdürülebilir politika ve planlamalar sayesinde hem yerel halkın hem de ziyaretçilerin memnuniyetini sağlamak mümkün olabilmektedir. Ancak her destinasyon için oluşturulmuş bir sürdürülebilirlik politikası ve planlamasının olduğunu söylemek mümkün değildir. Destinasyon için en uygun politikaları ve planları oluşturmak için destinasyon içinde turizmle ilgisi olan tüm paydaşlar, özellikle yerel halk sürece dahil edilmelidir. Aksi takdirde eksik ve yetersiz uygulamalar söz konusu olacaktır.

\section{Sürdürülebilir Destinasyonda Örgütlenme ve Önemi}

Ürünün mal veya hizmet ağırlıklı olmasına bakılmaksızın üretimde yapılması gereken ilk eylemlerden biri örgütlenmedir. Turizm sektöründe üretimin hem mal hem de hizmet şeklinde yapıldığı düşünülünce örgütlenmenin önemi daha da artmaktadır. Günümüz rekabet ortamında değişen şartlara uyum sağlayabilmek, her açıdan sürdürülebilir bir destinasyon oluşturabilmek ve gelen turistlerin 
tatmin edilmesi için tüm turizm paydaşları arasında işbirliğine ihtiyaç vardır. Kozak vd. (2012) destinasyon içerisinde işbirliğinin ve örgütlenmenin önemini 'domino etkisi' benzetmesiyle açıklamışlardır. Bu benzetmeyle anlatılmak istenen turistin bir destinasyonu ziyaretinde sadece tek bir unsurdan faydalanmadığı, aksine çok sayıda coğra$\mathrm{fi}$, ekonomik ve toplumsal unsurun birleşiminden oluşan bir turizm ürününü satın almasıdır.

Destinasyon için örgütlenme ile belirtilmek istenen dikey örgütlenme biçimidir. Genel olarak uygulanan sektörel meslek örgütlenmesi şeklindeki yatay örgütlenmeler destinasyonun isteklerine cevap verememektedir. Turizmde ve destinasyonlarda çok fonksiyonelli ve sektörlü dikey örgütlenmelere ihtiyaç duyulmaktadır. Dikey örgütlenmeyle tüm paydaşların bir araya getirilmesi ve ortak gayelere yönelik çalışması sağlanabilir. Zira Dünya Turizm Örgütü'nün destinasyonlara sürekli önerdiği, Türkçesi Destinasyon Yönetim Örgütü (DYÖ) olan Destination Management Organization (DMO) modeli dikey örgütlenmeye örnek teşkil etmektedir.

\section{Destinasyon Yönetim Örgütleri ve Sürdürülebilirlikleri}

Destinasyon yönetim örgütleri, iş veya tatil amacıyla seyahat etmeyi düşünen turistleri faaliyette bulundukları destinasyona çekmek için çalışmalar yapan ve koordinasyon çabası içinde olan örgütlerdir (Ersun ve Arslan 2011). Dünya Turizm Örgütü ise destinasyon yönetim örgütlerini, destinasyonları yönetmek ve pazarlamaktan sorumlu örgütler olarak tanımlamakta ve aşağıdaki kategorilerden birine dahil etmektedir (UNWTO 2004):

- Ulusal düzeyde turizmin yönetiminden ve pazarlamasindan sorumlu ulusal turizm otoriteleri veya örgütleri.

- Coğrafi bir bölgenin turizminin yönetilmesinden ve pazarlamasından sorumlu bölgesel veya eyalet bazında destinasyon yönetim örgütleri.

- Kent/kasaba veya daha küçük coğrafi alanların turizm yönetiminden ve pazarlamasından sorumlu yerel destinasyon yönetim örgütleri.

Yukarıda görüldüğü gibi farklı düzeyde faaliyet alanlarında çalışmalarını yürüten destinasyon yönetim örgütleri bulunmaktadır ve buna bağlı olarak da yürüttükleri faaliyetlerde değişmeler görülmektedir. Morrison vd. (1998) faaliyet alanına bakılmaksızın destinasyon yönetim örgütlerinin ekonomik sürücü, toplum pazarlamacısı, endüstri koordinatörü, yarı kamu temsilcisi ve toplum gururu yaratma gibi beş ana fonksiyonu bulunduğunu ileri sürmüştür.

Günümüz uygulamalarına bakıldığında, üst destinasyon yani ülke odaklı destinasyon yönetimi anlayışının terk edilmeye başlandığı görülmektedir. Turizmde başarılı olarak kabul edilen ülkelerin bütüncül olarak değil, mikro destinasyon olarak tabir edilen daha küçük alanlarda destinasyon örgütlenmelerine yöneldikleri gözlemlenmektedir.

Destinasyonda sürdürülebilirlik ve destinasyon örgütlenmeleri üzerine yapılan birçok çalışma bulunmaktadır (Jamal ve Getz 1995; Bramwell ve Sharman 1999; Presenza 2006; Bornhorst vd. 2009; Kozak vd. 2012). Bu çalışmalarda destinasyon içerisinde işbirliği ve örgütlenmenin önemine değinilmiştir. Kozak vd. (2012) ve Presenza (2006), paydaşlar arasında işbirliğinin gerekliliğini ortaya koyarken Jamal ve Getz (1995), işbirliğini oluşturmak için altı temel koşulun varlığından söz etmiştir. Bramwell ve Sharman (1999) ise paydaşlar arası işbirliği sonucunda ortaya çıkacak potansiyel faydalar üzerinde durmuştur. Ayrıca Dünya Turizm Örgütü de bu konu üzerinde sıklıkla durmakta ve çalışmalar yapmaktadır. Konunun önemine istinaden bu araştırmada da Çanakkale'nin mevcut durumu tespit edilmeye çalışılacaktır. Bu amaç doğrultusunda;

- Paydaşların sürdürülebilir destinasyon oluşturmada önemli gördükleri noktaların ve Çanakkale'nin eksiklerinin ortaya çıkarılması,

- Çanakkale'de bir destinasyon yönetim örgütü fikrinin oluşturulması,

- Oluşturulabilecek destinasyon yönetim örgütünün yapısına yönelik görüşlerin ortaya çıkarılması hedeflenmektedir.

\section{YÖNTEM}

Araştırmada veri toplama yöntemi olarak nitel araştırma yöntemi kullanılmıştır. Teknik olarak nitel araştırma yöntemleri arasında en önemlilerinden biri olan görüşme tekniği kullanılmıştır. Yarı yapılandırılmış anket formu yardımıyla paydaş görüşlerinin derinlemesine tespit edilmesi hedeflenmiştir. Ana teknik olan görüşme tekniğinin yanında doküman analizi ve gözlem de araştırmada kullanılan tekniklerdendir. 
Araştırmada kullanılan görüşme formu yazın taramasına bağlı kalınarak elde edilen kuramsal bilgilerden yola çıkarak yazarların ve nitel araştırma yöntemleri konusunda deneyimli olduğu bilinen uzman görüşlerinden yararlanılarak geliştirilmiştir. Görüşme formu geliştirilirken uzman akademisyenler ve sektör temsilcileri ile bir araya gelinmiştir. Görüşme formu iki aşamada dörder sorudan oluşmaktadır. Birinci aşamadaki sorular, Çanakkale destinasyonundaki paydaşların sürdürülebilirlik kavramıyla ilgili görüşlerini ve Çanakkale'nin sürdürülebilirlikteki durumunu anlamaya yöneliktir. İkinci aşamadaki sorularda ise Çanakkale destinasyonunda oluşturulabilecek destinasyon yönetim örgütünün yapılanması hakkında paydaş görüşlerinin ortaya çıkarılması hedeflenmiştir.

Araştırmanın evreni, Çanakkale ilindeki tüzel ve gerçek kişilerden oluşmaktadır. Örneklemi ise Çanakkale'de turizmle ilgisi olan paydaşlar oluşturmaktadır. Altta isimleri listelenmiş kurumların en üst düzey temsilcileri ile görüşmeler yapılmaya çalışılmıştır. Örnekleme dahil edilen kurumların Çanakkale'de turizme yön verilmesinde aktif rol oynayabilecek aktörlerden seçilmesine özen gösterilmiştir. Altta belirtilen kurumların en üst düzey yöneticileri veya yetkilendirdikleri kişilerle olmak üzere yüz yüze görüşmeler yapılmıştır. Toplamda yirmi dört paydaşla görüşülmüş ve görüşmeler ses kayıt cihazı ile kayıt altına alınmıştır.

- Merkezi Yönetim: Valilik (Turizmden sorumlu Vali Yardımcısı), Çanakkale İl Kültür ve Turizm Müdürlüğü, Güney Marmara Kalkınma Ajansı (Çanakkale Sorumlusu)

- Yerel Yönetim: Çanakkale Belediyesi, İl Özel İdare ve Kent Konseyi

- Sivil Toplum Kuruluşları: Çanakkale Ticaret ve Sanayi Odası, Çanakkale Sanayicileri ve İşadamları Derneği, Çanakkale Turistik Otelciler, işletmeciler ve Yatırımcılar Birliği Derneği, Çanakkale Profesyonel Rehberler Derneği ve Turizm Tanitma Derneği

- Özel Sektör (11): Ulaştırma İşletmeleri (2), Seyahat İşletmeleri (3), Konaklama İşletmeleri (4) ve Restoranlar (2)

- Diğer: Çanakkale Onsekiz Mart Üniversitesi Rektörlüğü, Çanakkale Onsekiz Mart Üniversitesi Turizm İşletmeciliği ve Otelcilik Yüksekokulu ve Kent Müzesi

\section{Nitel Araştırmada Geçerlilik ve Güvenirlik Çalışmaları}

$\mathrm{Bu}$ araştırmada nitel verilerin geçerlik ve güvenirliğinin sağlanmasında önemli yöntemlerden biri olan "çeşitleme" kullanılmıştır. " Çeşitleme, araştırma sorusuna yönelik olarak toplanan verilerin farklı yöntemlerle elde edilmesi ve bu şekilde elde edilen bulguların inandırıcılığının test edilmesi için kullanılır" (Yıldırım ve Şimşek 2000).

Araştırmada Patton'ın (2002) belirtmiş olduğu üç farklı çeşitleme gerçekleştirilmiştir:

- Veri Çeşitlemesi: Veriler farklı gruplardan, farklı çevrelerden veya farklı zamanlarda toplanmıştır.

- Araştırmacı Çeşitlemesi: Aynı araştırmada birden fazla araştırmacı yer almıştır.

- Yöntemsel Çeşitleme: Aynı araştırmada veri toplamak için birden fazla veri toplama tekniği kullanılmıştır.

Araştırmanın iç geçerliliğini sağlamak için, veri toplama araçlarının hazırlanmasında ve verilerin toplanmasında kavramsal çerçeve rehber olarak alınmıştır. Araştırma bulguları, gözlem, görüşme ve doküman analizi olmak üzere üç farklı veri kaynağından elde edilmiştir. Böylece üç farklı veri kaynağından elde edilen bulgular karşılaştırmalı olarak incelenmiştir. Açık ve anlaşılır olmayan olgu ve olaylar belirlenerek bulgulara dahil edilmemiştir.

Araştırmanın dış geçerliliği ile ilgili olarak çalışma grubunun ve araştırma ortamının özellikleri detaylı olarak tanımlanmıştır. Araştırmada dış güvenirliğin sağlanması amacıyla, kullanılan gözlem, görüşme ve doküman inceleme yöntemleri ile bu yöntemlerin aşamaları açı bir biçimde tanımlanmıştır. Ayrıca katılımcı görüşmeleri aracılığıyla veri toplama, bu verileri betimsel ve içerik analizi yöntemleri ile analiz etme, bulguları yorumlama ve sonuca ulaşma konularında yapılan çalışmalar açıklanmıştır. Çalışmada ulaşılan sonuçlar, elde edilen verilerle ilişkili bir biçimde sunulmuştur.

Araştırmada iç güvenirlik ile ilgili olarak ise araştırma sorusu açık bir biçimde ifade edilmiş ve diğer aşamalarla tutarlı biçimde sunulmuştur. Ayrıca araştırma sonuçları, üç farklı veri toplama tekniği ile elde edilen verilerle tutarlı biçimde ortaya konmuş, veriler araştırma sorusunun gerektirdiği biçimde katılımcılardan elde edilmiştir. Verilerin 
analizi birden fazla araştırmacı tarafından gerçekleştirilmiş ve karşılaştırma yapılarak tutarlılık göstermeyen veriler, araştırma kapsamı dışında bırakılmıştır.

\section{VERI ANALIZi}

Toplanan veriler bilgisayar ortamına aktarılarak altmış beş sayfalık ham veri elde edilmiştir. Elde edilen ham veriler içerik analizine tabi tutularak çözümlenmiştir. İçerik analiziyle, toplanan ham veriler kavramsallaştırılmış ve kodlar oluşturulmuştur. Ortaya çıkarılan kodlar benzerlik ve farklılıklarına göre gruplandırılmış ve birbiriyle ilişkili olan kodlar birleştirilerek tematik kodlama yapılmıştır (Yıldırım ve Şimşek 2011). Toplanan ham verilerin içerik analiziyle değerlendirilmesi sonucu Tablo 1'de görüldüğü şekilde sürdürülebilir destinasyon süreci ve sürdürülebilir destinasyonda örgütlenme başlıkları altında 41 kod belirlenmiştir.

Birbiriyle ilişkisi olan kodların birleştirilmesi sonucu Tablo 1'de yer alan, sürdürülebilir destinasyon süreci ve sürdürülebilir destinasyonda örgütlenme olmak üzere iki ana tema belirlenmiştir. Sürdürülebilir destinasyon süreci ana temasından yola çıkarak altyapı, eğitim, pazarlama ve tanıtım alt temaları oluşturulmuştur. Sürdürülebilir destinasyonda örgütlenme ana teması ise örgütte liderlik, örgüt finansmanı ve örgüt yapısı alt temalarını kapsamaktadır.

Tablo 2'de sürdürülebilir destinasyon süreci ve sürdürülebilir destinasyonda örgütlenme ana temalarından yola çıkılarak oluşturulan alt temalar ve sorulan sorular karşılığında bu temalara ne kadar değinildiği gösterilmektedir.

\section{BULGULAR}

\section{Sürdürülebilir Destinasyon Sürecinde Altyapı}

Yapılan görüşmeler sonucunda altyapı teması altında ulaşım, yatırım, fiziksel altyapı ve hizmet kalitesi unsurları ön plana çıkmaktadır. Paydaşların çoğu, sürdürülebilirlikte ulaşım ve konaklama imkânlarının önemine değinmekle beraber Çanakkale'nin bu konularda yetersiz olduğu fikrinde birleşmektedirler.

Çanakkale'de ulaşım konusunda büyük sıkıntılar yaşanmaktadır. Havayolu ulaşımının düzenli olarak işler hale getirilememesi paydaşlar tarafından özellikle üzerinde durulan bir noktadır.
Seyahat acentesi sahibi ve bir STK yetkilisi deneyimlerinden yola çıkarak ulaşımdaki sıkıntının Çanakkale'ye yaşattığı olumsuzlukları ifade etmiştir:

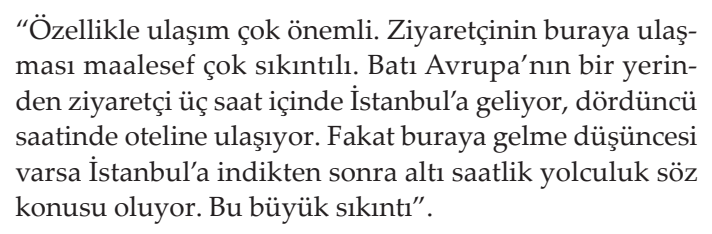

Ulaşım konusunda havayolu dışında çok tartışılan konulardan biri de yat limanıdır. Yat limanının büyüklüğü, yapılacak yer ve benzeri birçok konuda değişik fikirler ve tartı̧̧malar her platformda kendini göstermektedir. Özel sektör temsilcisi ve aynı zamanda bir STK'nın yöneticisi, yat limanının gerekliliğinin kaçınılmaz olduğunu belirtmektedir:

\footnotetext{
"Turizmde deniziniz varsa yat limanınız olmak zorunda. Ben turistik kentim diyorsan, üç tarafı deniz olan bir kentsen yat limanın olmak zorunda. Bunun başka bir şekli yok. Çanakkale bunu tartışıyorsa kent olarak turizme hazır değil demektir. Bir tekne geldiğinde belediyenin yat limanı diye gösterdiği bir yer var ama yat limanı dersek gülerler".
}

Paydaşların eksiklik olarak üzerinde durduğu diğer bir konu, Çanakkale'de konaklama imkânlarının yeterli seviyede olmamasıdır. Ortak görüş olarak, Çanakkale'ye yatırımcı çekilerek üst düzey konaklama tesislerin oluşturulması öne çımaktadır. Hatta ulusal ve uluslararası zincir otellerin getirilmesi gerektiği ifade edilmiştir. Bu konuda özel sektör temsilcisi, aşağıdaki şekilde görüş bildirmiştir:
“Bugüne kadar Çanakkale'de oluşmuş potansiyel, yerli yatırımcının elinden gelendir. Dışarıdan yatırımcı çek- meliyiz. Sermaye olmadan profesyonel turizm hayal- dir. Devlet politikasıyla buraya yatırımcı çekmeliyiz. İlimizdeki tek beş yıldızlı otelimiz, Çanakkale millet- vekili olan Enerji Bakanı'nın özel çabası ile inşa edildi. Çeşitli teşviklerle büyük yatırımçların ve markaların ilimize çekilmesi gerekiyor. Marka işletmeler siz farkın- da olmadan turizmin gelişimi için katkı yaparlar, diğer mekânlar kendilerine çekidüzen verirler ve yetişmiş bir profesyonel kadro oluşumuna katkıda bulunurlar".

Yerel yönetim temsilcisi turizm yatırımları için alanlar oluşturmaya çalıştıklarını ve konaklama tesisleri için teşvik edici çalışmaları olduğunu ifade etmiştir:

\footnotetext{
“Mesela deniz kıyılarını konuta açmıyoruz. Örneğin Kredi Yurtlar Kurumu öğrenci yurdu. Orada, deniz kıyısında öğrenci yurduna gerek yok. Turizm yatırımı yapmayı düşünüyoruz".
} 


\begin{tabular}{|c|c|c|c|}
\hline Görüşme Kodları & Frekans 363 & $\begin{array}{c}\text { Toplam Yüzdesi } \\
\text { (\%) }\end{array}$ & Frekans Yüzdesi (\%) \\
\hline Sürdürülebilir Destinasyon Süreci & 175 & 48,20 & 100,00 \\
\hline Altyapı & 59 & 16,25 & 100,00 \\
\hline Fiziksel altyapı & 10 & 2,75 & 16,94 \\
\hline Yatırım & 13 & 3,58 & 22,03 \\
\hline Ulassım & 10 & 2,75 & 16,94 \\
\hline Hizmet kalitesi & 10 & 2,75 & 16,94 \\
\hline Koruyarak kullanma dengesi & 7 & 1,92 & 11,86 \\
\hline İmkanlar & 6 & 1,65 & 10,16 \\
\hline Bürokrasileri assmak & 2 & 0,55 & 3,38 \\
\hline Çalışma şartları & 1 & 0,27 & 1,69 \\
\hline Pazarlama ve Tanıtım & 91 & 25,06 & 100,00 \\
\hline Ortalama geceleme süresi & 16 & 4,40 & 17,58 \\
\hline Tanitım & 12 & 3,30 & 13,18 \\
\hline Alternatif turizm & 10 & 2,75 & 10,98 \\
\hline Planlama & 12 & 3,30 & 13,18 \\
\hline Çekicilikler & 21 & 5,78 & 23,07 \\
\hline Sezonu yaymak (Uzatmak) & 7 & 1,92 & 7,69 \\
\hline Fiyat politikası & 6 & 1,65 & 6,59 \\
\hline Paydas iletisimi & 3 & 0,82 & 3,29 \\
\hline Pazarlama & 3 & 0,82 & 3,29 \\
\hline Pazar cesitlendirmesi & 1 & 0,27 & 1,09 \\
\hline Eğitim & 25 & 6,88 & 100,00 \\
\hline Ulusal ve uluslararası gelismeleri izleme & 4 & 1,10 & 16,00 \\
\hline Eğitim ve bilinçlendirme & 18 & 4,95 & 72,00 \\
\hline Turizmi benimseme (Yerel halk) & 3 & 0,82 & 12,00 \\
\hline Sürdürülebilir Destinasyonda Örgütlenme & 188 & 51,80 & 100,00 \\
\hline Örgüt Yapısı & 111 & 30,57 & 100,00 \\
\hline Merkezi yönetim & 24 & 6,61 & 21,62 \\
\hline Yerel yönetim & 24 & 6,61 & 21,62 \\
\hline Özel sektör & 24 & 6,61 & 21,62 \\
\hline Sivil toplum kurulusları & 18 & 4,95 & 16,22 \\
\hline Üniversite & 13 & 3,60 & 11,71 \\
\hline Yerel halk & 8 & 2,19 & 7,21 \\
\hline Örgütte Liderlik & 24 & 6,61 & 100,00 \\
\hline Merkezi yönetim (Valilik) & 13 & 3,60 & 54,16 \\
\hline Yerel yönetim (Belediye) & 1 & 0,27 & 4,17 \\
\hline Sivil toplum kuruluşları & 1 & 0,27 & 4,17 \\
\hline İ Kültür ve Turizm Müdürlüğü & 4 & 1,10 & 16,67 \\
\hline Özel Sektör & 2 & 0,55 & 8,33 \\
\hline Yönetim kurulu & 3 & 0,82 & 12,50 \\
\hline Örqüt Finansmanı & 53 & 14,60 & 100,00 \\
\hline Özel sektör & 10 & 2,76 & 18,87 \\
\hline Merkezi yönetim & 19 & 5,23 & 35,85 \\
\hline Yerel yönetim & 8 & 2,19 & 15,10 \\
\hline Sivil toplum kuruluşları & 7 & 1,92 & 13,21 \\
\hline Güney Marmara Kalkınma Ajansı & 5 & 1,41 & 9,43 \\
\hline Turizm vergileri & 1 & 0,27 & 1,88 \\
\hline$A B$ hibeleri & 2 & 0,55 & 3,77 \\
\hline Örgütün organizasyon ve faalivetleri & 1 & 0,27 & 1,88 \\
\hline
\end{tabular}




\begin{tabular}{|c|c|c|c|c|c|c|}
\hline TEMALAR & \multicolumn{3}{|c|}{ Sürdürülebilir Destinasyon Süreci } & \multicolumn{3}{|c|}{ Sürdürülebilir Destinasyonda Örgütlenme } \\
\hline SORULAR & Altyapı & Eğitim & $\begin{array}{c}\text { Pazarlama ve } \\
\text { Tanitım }\end{array}$ & $\begin{array}{l}\text { Örgütte } \\
\text { Liderlik }\end{array}$ & $\begin{array}{c}\text { Örgüt } \\
\text { Finansmanı }\end{array}$ & Örgüt Yapısı \\
\hline $\begin{array}{l}\text { Destinasyonun } \\
\text { sürdürülebilirliğini } \\
\text { sağlamak için neler } \\
\text { yapılması gerekir? }\end{array}$ & 15 & 10 & 19 & & & \\
\hline $\begin{array}{c}\text { Çanakkale'nin } \\
\text { sürdürülebilirlik } \\
\text { açısından mevcut } \\
\text { durumunu } \\
\text { değerlendirir misiniz? }\end{array}$ & 14 & 5 & 24 & & & \\
\hline $\begin{array}{c}\text { Çanakkale'de } \\
\text { paydaşlar arasında } \\
\text { örgütlü çalışmalar } \\
\text { yapılmakta mıdır? }\end{array}$ & & & & & & 24 \\
\hline $\begin{array}{c}\text { Sürdürülebilirliğe } \\
\text { yönelik çalışmalarınız } \\
\text { var mıdır? }\end{array}$ & 7 & 3 & 19 & & & \\
\hline $\begin{array}{c}\text { Oluşturulacak } \\
\text { destinasyon yönetim } \\
\text { örgütüne kimler dahil } \\
\text { edilmelidir? }\end{array}$ & & & & & & 24 \\
\hline $\begin{array}{c}\text { Oluşturulacak } \\
\text { destinasyon yönetim } \\
\text { örgütünün liderliğini } \\
\text { hangi kurum/kişi } \\
\text { üstlenmelidir? }\end{array}$ & & & & 24 & & \\
\hline $\begin{array}{c}\text { Oluşturulacak } \\
\text { destinasyon yönetim } \\
\text { örgütünün finansı } \\
\text { nasıl sağlanmalıdır? }\end{array}$ & & & & & 24 & \\
\hline $\begin{array}{c}\text { Destinasyon yönetim } \\
\text { örgütünün } \\
\text { sürdürülebilirliğe } \\
\text { yönelik faaliyetleri } \\
\text { neler olmalıdır? }\end{array}$ & 16 & 10 & 19 & & & \\
\hline
\end{tabular}

Sürdürülebilir destinasyon sürecinde hizmet kalitesi de paydaşlar tarafından ısrarla üzerinde durulan konulardan biridir. Hizmet kalitesi kapsamında destinasyon içerisinde turistlerin faydalanacağı tüm kamu ve özel işletmeleri ve bu işletmelerin faaliyetlerini ele almak gerekmektedir. Çanakkale açısından bir değerlendirme yapıldığında gerek konaklama işletmelerinin gerekse turistik restoranların ve en önemlisi çekicilikler kapsamında değerlendirilen eğlence ve alışveriş olanaklarının tatmin edici düzeyde olmadığı gözükmektedir. Özel sektör temsilcisi eğlence ve alışveriş imkânlarının önemini ve Çanakkale'nin bu açıdan eksik olduğunu ifade etmiştir.

"Gece hayatı şart. Gece hayatının olmadığı bir yer, turizm destinasyonu olmuyor. Gece hayatından kastım; 
disko, kulüp gibi eğlence mekanları. Avrupalının isteyeceği tarzda bir gece hayatı yok burada. Gece hayatında turisti yollayacağımız, güzel menüsü olan, turistin kazıklanmayacağı, İngilizce hizmet alabileceği yerlerin sayısı çok fazla değil Çanakkale'de. Alışveriş hizmeti başka önemli bir konu. Turist alışverişi sever. Düşünsenize turizm destinasyonu olma çabamız var ama bir tane alışveriş merkezimiz yok. Bu büyük bir handikap".

Bir destinasyonda turizmin başarılı bir şekilde gelişmesi için yeterli fiziksel altyapı olanaklarının varlığı yaşamsal öneme sahip bir faktördür. Ulaştırma tesisleri ve hizmetleri, su sağlanması, elektrik enerjisi, sıvı ve katı atık sistemi ve iletişim, destinasyonda turizmin gelişimi için en gerekli fiziksel altyapı unsurlarıdır.

Paydaşlar Çanakkale destinasyonunda fiziksel altyapının tam oturtulamadı ğını belirtmişlerdir. Ağırlıklı eleştiri Çanakkale için hem doğal güzellikleri olan hem de önemli bir su kaynağı olan Kaz dağlarındaki altın madenine yönelik çalışmalar üzerinedir. Yerel yönetim temsilcisinin bu konudaki düşünceleri aşağıdaki şekildedir.

\begin{abstract}
“Çanakkale'de Kaz dağları konusu var. Kaz dağları tek başına turizm potansiyeli. Sağlık turizmi açısından oradaki sıcak su kaynakları ve özellikle göğüs hastalıkları için oksijenin bol olması çok önemlidir. Ama biz ağaçları keserek, altın arayarak, oraları tahrip ederek turizmden vazgeçmiş oluyoruz. Bu çalışmalardan temiz su kaynaklarımızın olumsuz etkilenmemesi mümkün mü? ... Durum böyleyken sürdürülebilirlikten bahsedemeyiz... Sürdürebilmek ve destinasyon olarak korumak lazım. Koruma kullanma dengesi sağlanmalıdır".
\end{abstract}

\section{Sürdürülebilir Destinasyon Sürecinde Pazarlama ve Tanıtım}

Destinasyon marka kimliğini ve onu diğer destinasyonlardan ayıran özelliklerini belirlemek ve pazarlama çalışmalarında onları vurgulamak, bir destinasyonu uluslararası turizm pazarında daha rekabetçi bir pozisyona taşıyacak temel unsurlardir. Geleneksel pazarlama faaliyetlerinden vazgeçmeyen ve destinasyon kaynakları açısından farklı olmakla birlikte bu farklılı̆̆ pazarlamakta başarılı olamayan destinasyonların turizm geleceği tehlike altında bulunmaktadır (Özdemir 2008). Destinasyon yönetim örgütleri dolayısıyla destinasyon yönetim örgütüne dahil olan her paydaş destinasyonun pazarlamasından sorumludur. Paydaşların destinasyon pazarlama unsurları olan konumlama, imaj ve markalaşma çalışmalarında üzerlerine düşenleri yapmaları gerekmektedir.
Görüşülen paydaşların genel çoğunluğunun ortak görüşü Çanakkale'de ortalama geceleme süresinin düşük olduğudur. Ortalama geceleme süresini artırmak için alternatif turizme yönelinmesi ve var olan çekiciliklerin tanıtımının ve pazarlamasının iyi yapılması düşüncesi ön plana çıkmaktadır. Üniversite temsilcisi termal ve kongre turizmini ön plana çıkararak alternatif turizme yönelmenin mantıklı olabileceğini aşağıdaki sözleriyle ortaya koymuştur:

\begin{abstract}
"Çanakkale'de konaklama süresi sıkıntısı mevcut. Bu temel sorundur. Kalış süresi uzatılmalı. Bu konuda Çanakkale'nin alternatif turizme yönelmesi mantıklı olabilir. Şu anda Çan bölgesinde termal turizmle ilgili çalışmalar var. Kaz dağlarında outdoor aktiviteleri yapılabilir. Kongre turizmi de yapılabilir. Çanakkale; İstanbul, İzmir gibi büyük illere yakın ve kongre turizmi gibi alternatif turizm türleri geliştirilebilir".
\end{abstract}

Bir STK yöneticisi günübirlik gelen ziyaretçinin destinasyona hiçbir katkısının olmadığını ifade ederek, kesinlikle alternatif turizm faaliyetleriyle konaklama süresinin artırılması gerektiği yönünde görüş bildirmiştir.

\begin{abstract}
"Gelen konukların konaklamasının artırılması için alternatiflerin çoğaltılması, önemli bir konudur. Gelen ziyaretçiler bir gün Gelibolu savaş alanlarını ziyaret ediyorsa, bir gün de Assos ve Truva ören yerlerini gezebilirler. Turizmde çeşitlilikler sayesinde konaklama süresi kesinlikle uzatılmalıdır. Mevcut günübirlik turlar Çanakkale'ye hiçbir katkı sağlamamaktadır".
\end{abstract}

Yerel yönetim temsilcisi Çanakkale destinasyonunun çekiciliklerinden bahsederek potansiyel olduğunu ve konaklama süresinin çekiciliklerin ortaya çıkarılarak artırılabileceğini belirtmekle beraber pazarlamada sıkıntılar yaşandı̆̆ını dile getirmektedir:

\footnotetext{
"Çanakkale; tarihi, coğrafyası, doğal kaynaklarıyla çeşitli turizm alanlarında hizmet verebilecek kapasitede. Vatandaş buraya gelince Truva'yı gezip gitmesin. Alexandrei Troas, Assos ve Truva yolu gibi değerleri turizmin ticari portföyüne koyamıoruz".
}

İl Özel İdare temsilcisi, Çanakkale'nin tanıtım konusunda eksikliğini verdiği bir örnekle somutlaştırmıştır:

\footnotetext{
“Truva'nın Çanakkale'de olduğunu bilen insan sayısı ile Truva'yı bilen insan sayısının doğru orantılı olduğunu düşünmüyorum. Truva'yı herkes biliyor ama Truva nerede dediğiniz zaman ses yok. Mustafa Erdoğan "Sultan of the Dance" ile Truva'yı oynadı. Orada ilk sunumda geçiyor, Truva Çanakkale'dedir diye. Bu güzel bir adımdır".
} 
Bir STK yöneticisi ve aynı zamanda özel sektör temsilcisi yakın pazarlara yönelik süreklilik arz eden tanitım faaliyetleri sayesinde konaklama süresini artırabilmenin mümkün olacağını ve yöneticisi olduğu STK ile buna yönelik çalışmalar yaptıklarını belirtmiştir:

\begin{abstract}
“Kayıtlara göre geceleme süresi 1-2 gecedir. İlk etapta bunu iki gün bile yaparsak çok çok önemli. Bunu başarmak için acentelerin Çanakkale'de iki gün kalınması için programlar yapması lazım. Dışarıdan, İstanbul'daki acenteler İstanbul'u gezdiriyor sonra Anadolu turu adı altında Çanakkale, Bergama, Efes böyle bir tur yaptır1yor. Bizde bir gece kalıyor, Truva yapiyor devam ediyor. Yunanistan, Bulgaristan, Romanya, Sırbistan. Şimdi Makedonya. Balkan pazarı bize yakın pazar. Sabırla bu pazarlara yoğunlaşmak gerek".
\end{abstract}

\section{Sürdürülebilir Destinasyon Sürecinde Eğitim}

Yerel halkın turizmi benimsemesi ve çeşitli konularda bilinçlendirilmesi üzerinde önemle durulması gereken konulardandır. Üniversite temsilcisi yerel halk tarafından benimsenmeyen turizm faaliyetlerinin başarılı olamayacağının altını çizmektedir:

\footnotetext{
"Bazı illerde turizm ve turist istenmez, turistlere karşı önyarg1 vardır. Bu tür illerde ne kadar çok uğraşırsanız uğraşın, destinasyonu sürdürülebilir kılmak zordur. Fakat ilin yerel halkı bu işe gönüllüyse temelden bu işi yapmak daha kolaydır".
}

Üniversiteden diğer bir temsilci de yukarıdaki görüşe paralel olarak yerel halkın turizmin olumlu ve olumsuz yanları hakkında bilgilendirilmesi ve ona göre desteklerinin beklenmesi gerektiğini belirtmiştir:

\begin{abstract}
“Çoğu zaman atlanıyor ama yerel halkı da sürece dahil etmeliyiz. Yerel halk tarafından benimsenmeyen, kabul edilmeyen faaliyetlerle destinasyon oluşturmak, hele ki sürdürülebilir destinasyon oluşturmak çok zordur. Halkın bilinçlendirilmesi, daha sonra konunun önemi ortaya konularak bu işi benimsemesi ve destek vermesi önemlidir. Bunların hepsi arka arkaya gelmektedir. Önce halk olayın artısını, eksisini öğrenecek ki sonra ben buna destek verebilirim diyecek. Onların destek vermesi konusunda da kamu sektörü yol gösterici rol oynayacaktır".
\end{abstract}

Yerel halkın bilinçlendirilmesinin yanında sektörde çalışan, turizmle ilişkisi olan, gelen ziyaretçiyle doğrudan iletişimi olan insanların eğitimi de önem arz etmektedir. Özel sektör temsilcisi Çanakkale'de bu konudaki eksiklikleri aşağıdaki şekilde ifade etmiştir:
“Bizim çarşıdan alışveriş yapamazsın. Çünkü etiketlerde Euro etiketleme yok. İkincisi adam İngilizce bilmiyor. Nasıl satacak malını? Kendi müşterimle alışverişe çıktığım zamanlar oluyor ve bu durum ciddi bir dezavantaj".

Bir STK temsilcisi ise kentte ulaşımı sağlayan çalışanların en azından anlaşabilecekleri düzeyde dil öğrenmelerinin gerekliliğini ifade ederek ilgili kurumların çalışmalar yapmasını önermektedir:

"Sektörde çalışan insanların iletişimini iyileştirmesi ge-
rekir. Şu an kullanılan uluslararası dil İngilizcedir. Şo-
förler Odası'yla irtibata geçip taksicilere, Belediye'yle
irtibata geçip halk otobüsü şoförlerine en azından anla-
şabilecekleri düzeyde dil öğrenmeleri sağlanmalıdır. Bu
çok önemli bir unsurdur. Bunun için kurslar açlabilir".

Özel sektör temsilcisi turistik çekiciliklerimizi gün yüzüne çıkarmak amacıyla alanında uzman insanlarla çalışılması gerektiğini belirterek üniversitenin burada çok önemli bir paydaş olduğunu vurgulamaktadır:

\begin{abstract}
“En büyük sıkıntı, tek bilinen yerimiz Truva. Truva tabî ki önemli ama Truva'nın ötesinde de Çanakkale'de önemli tarihi yerler var. Yabancı turistlerin dikkatini çekebiliriz. Alexandria Troas diye bir yer var ve bunu çekici hale getirmemiz lazım. Medya ile çekim noktası oluşturulmalı".
\end{abstract}

\section{Örgüt Yapısı}

Paydaşlar destinasyon açısından belirli bir problem alanı ile ilgilenen bireyler, gruplar veya kuruluşlar olarak ifade edilmektedir (Cooper vd. 2009). Sheehan ve Ritchie (2005) yaptıkları çalışmada toplam otuz iki turizm paydaşını belirlemiştir. Marmara, Ege ve Akdeniz bölgeleri üzerinde yapılan bir başka araştırmayla da destinasyon içerisindeki yirmi dört paydaş önem derecesine göre sıralanmış ve valilik, belediye, il özel idare en önemli üç paydaş olarak ortaya koyulmuştur (Semerciöz vd. 2008). Paydaş olarak görülen farklı tarafların her birisinin kendisine özgü faaliyetleri bulunmakta ve yap-boz parçası olarak görülmektedir. Eğer yapbozdan tek parça uymuyorsa tüm destinasyonda turizm deneyiminin yok olacağı ifade edilmektedir (Saftic vd. 2011). Çanakkale destinasyonu için yaptığımız araştırmada da yukarıdaki çalışmalara paralel olarak oluşturulabilecek bir destinasyon yönetim örgütünün yüksek katılımlı olması fikri ön plana çıkmıştır. Görüşülen paydaşların hepsi merkezi yönetimin, yerel yönetimin ve özel sektörün örgüte dahil edilmesi gerektiğini ifade etmiştir. Bu 
üç paydaş dışında STK'lar, üniversite ve yerel halk da örgüte dahil edilmesi gereken paydaşlar olarak görülmektedir.

Özel sektör temsilcisi destinasyonun geniş pazarlara hitap etmesi için geniş tabanlı destinasyon yönetim örgütü oluşturulması gerektiğini ifade etmiştir:

“Gönüllülerden tutun, ilin mülki amirlerine, yerel yönetimler, STK'lar basın, üniversite, herkesi dahil edebilirsin. Destinasyonun geniş bir pazara hitap etmesi için destekleyenlerin de çok geniş bir yelpazede olması avantaj olur".

Bir STK yöneticisi de geniş katılım sayesinde farklı düşüncelerle ilerleme kaydedileceğini belirtmiştir:

\begin{abstract}
"Turizmin çok geniş bir kapsama alanı vardır. Turizm paydaşları olarak otelcileri, esnafları, STK'ları, yerel yönetimi, merkezi yönetimi ve en önemlisi üniversiteyi sayabiliriz. Çanakkale'nin havasını teneffüs eden, turizmle ilgisi olan herkesi içine alan geniş tabanlı, katılımlı bir örgüt kurulmalıdır. Ne kadar katılım olursa o kadar farklı fikir üretilecektir".
\end{abstract}

Merkezi yönetim temsilcisi kamu kurumlarının tüm birimleriyle destinasyon yönetim örgütüne dahil edilmesinin gerekliliğine vurgu yapmıştır:

\begin{abstract}
“Öncelikle dünyadaki örneklerine bakmamız gerekmektedir. Var olan bir şeyden faydalanmak lazım. Artılarını ve eksilerini değerlendirmemiz ve kendi özgün modelimizi çıkarmamız gerekmektedir. Tabi ki otelciler, acenteler, ulaşımı sağlayan işletmeler, yeme içme tesisleri, hediyelik eşya satan dükkânlar, herkes bir yerde olmalıdır. Kamu tüm birimleriyle işin içinde olmalıdır. Çünkü sorunlar ve çözümler çeşitli. Tüm kamu kurumları, yerel yönetimler ve tüm turizm unsurlarını işin içine dahil etmeliyiz".
\end{abstract}

\section{Örgütte Liderlik}

Destinasyon yönetim örgütüne kimlerin dahil edileceğine ilişkin sorunun yanı sıra cevap bekleyen önemli bir soru da hangi kurum veya kişinin liderliği üstleneceğidir. Bu konuda destinasyonun içinde bulunduğu aşamaya dikkat etmek gerekmektedir. Örneğin, turizm alanında yeni gelişmekte olan destinasyonlar için kamunun önderliğinde bir örgütlenme makul olabilirken, yeterli derecede gelişmiş ve turizmin önemli bir endüstri olduğu destinasyonlarda kamunun katılımının ve etkisinin azaltılması ve özel sektörün lokomotif rolünü üstlenmesi gerekmektedir (Atay ve Akyurt 2007). Çanakkale' nin de gelişmekte olan bir destinasyon olduğu düşüncesiyle destinasyon örgütünde lide- rin merkezi yönetim, yani valilik kurumu olması uygun olacaktır. Araştırmamız sonucunda da yirmi dört paydaşın on üçü valiliğin liderliği üstlenmesi gerektiğini ifade ederek yukarıdaki görüşü desteklemektedir.

Liderlik görevini valilik kurumunun üstlenmesi gerektiğini belirtmekle beraber belirli özellikleri taşıması üzerinde özellikle durulmuştur. Bir özel sektör temsilcisi liderlik yapacak kurumda olması gereken özellikleri aşağıdaki ifadelerle açıklamıştır:

\footnotetext{
“Liderin kim olmasından çok özellikleri daha önemlidir. İsim vermektense şu özelliklere sahip olan kişi veya kurum, destinasyon yönetim örgütünün lideri ya da destinasyon yönetiminde en üst noktadadır, diyebiliriz. En basitinden ikna kabiliyetinin olması gerekir. Paydaşları bir araya getirmek ve bu birlikteliği bir bütün olarak tutmak çok önemlidir. Önemli olan birlikteliğin sürdürülebilirliğini sağlamaktır. Bundan sonra yaptırım ve finans gücünün de olması gerekmektedir".
}

Bir başka özel sektör temsilcisi ise valilik kurumunun liderliği üstelenmesi gerektiğini belirtmekle beraber bazı özellikleri taşımasının gerekliliğini ifade etmiştir:

\begin{abstract}
“Lider tabii ki valilik olacak. Vali mülki amirdir. Ülkenin başı Cumhurbaşkanı ise ilde de baș validir. Karar verme yetkisi tam olarak onda olmasa da vali başta olacak. Ama valinin de öyle birisi olması lazım ki vizyonu geniş, Çanakkale'yi bilen, turizmden anlayan, buranın turizm ve üniversite kenti olmasına çaba gösterecek özellikleri taşıması gerekmektedir".
\end{abstract}

Merkezi yönetim yani Valilik temsilcisi de liderliği valiliğin üstlenmesi gerektiğini diğer paydaşlar karşısında kurum olarak avantajlarını ortaya koyarak açıklamıştır:

\begin{abstract}
"Valilikten başka lider düşünemiyorum. Alan çok geniş, dağınık bir yapı var ve sorunlar da dağılıyor. Hepsinin ortak çatısı ise valilik. Hem turizm çeşitliliği aç1sından hem sektörel çeşitlilik açısından hepsinin ilişkide bulunduğu, hepsinin bir sorunu olduğunda geldiği yegâne birim valilik oluyor. Yaptırımı ve sorumluluğu olan kurum valiliktir. Belediyenin alanı çok sınırlı. Özel sektörümüz ise maddi yönü açısından çok kuvvetli değil ki liderlik vasfını yapabilsin".
\end{abstract}

\section{Örgüt Finansmanı}

Örgütün finansmanı konusunda görüşmeciler, herkesin katkısının olması gerektiğini ifade etmekle birlikte, ağırlığın kamu yönetiminde olması gerektiğini de ilave etmişlerdir. Özellikle büyük yatırımlar söz konusu olduğunda kamunun desteğinin kaçınılmaz olduğu görüşünde birleşilmiştir. Bir 
STK yöneticisi, yapılması gündemde olan Truva Müzesi örneğinden yola çıkarak görüşlerini aşağıdaki şekilde açıklamıştır:

\begin{abstract}
“Devletin bazı şeyleri sübvanse etmesi gerekmektedir. Bizler vergi veriyoruz. Örneğin Truva'nın bir müzesi yapılacaksa bu işi bir şahsın yapması çok zor. Burada devreye devletin girmesi gerekmektedir. Zaten böyle bir müze yapıldığı zaman inanılmaz bir katkı sağlanacaktır. Ciddi bir ziyaretçi akımıyla yatırım kendini amorti edecektir ve kâra geçecektir. Turizmin özel sektör paydaşlarının da elini taşın altına sokması gerektiğini düşünüyorum. Güney Marmara Kalkınma Ajansına da büyük görevler düşmektedir".
\end{abstract}

Merkezi yönetim temsilcisi de kamu desteğinin kaçınılmaz olmasını belirtirken diğer paydaşların da örgütü ve faaliyetlerini benimsemesi açısından kesinlikle katkıda bulunması gerektiğini ifade etmiştir:

\begin{abstract}
"Kamunun desteği olduğu gibi diğer unsurların da desteği olmalıdır. Ben on sekiz yıllık idarecilik hayatımda şunu gözlemledim. İnsanlar katkı sundukları derecede kıymet veriyorlar, öyle sahipleniyorlar. Bir insanın veya bir kurumun bir konuyu sahiplenmesini istiyorsan onu sorumluluk ortağı yapmalısın. Bu konuda o yüzden herkes gücüne göre maddi kaynak vermelidir. Turizm Altyapı Birlikleri, İl Özel İdare, Kültür ve Turizm Bakanlığı'ndan finanslar sağlanabilir".
\end{abstract}

Üniversite temsilcisi ise Avrupa Birliği projelerinde turizmin öncelikli sektörlerden biri olduğunu belirterek görüşlerini aşağıdaki şekilde ifade etmiştir:

\begin{abstract}
"Finansal kaynak için kamudan ağırlıkla destek almak gerekir. Valilik burada ön plana çıkar. AB hibe projelerinden de yararlanılabilir. $\mathrm{AB}^{\prime}$ nin yatırım planlarına ve kabul edilen projelerine baktığınız zaman turizmin öncelikli alanlardan olduğu görülmektedir. Turizm için oradan fon sağlanabilir".
\end{abstract}

\section{SONUÇ VE ÖNERILER}

Günümüzde destinasyon yönetim örgütleri, destinasyon içerisinde sürdürülebilir turizmi sağlamak adına önemli kurumlardır. İyi organize olmuş ve sağlıklı plan ve politikalar yürüten destinasyon yönetim örgütleri sayesinde turizme taraf olan her kesimin memnuniyetini artırmak mümkün olmaktadır. Bu düşünceden yola çıkarak bu çalışmada, Çanakkale'nin sürdürülebilirlikteki mevcut durumu ve oluşturulabilecek bir destinasyon yönetim örgütünün yapısı hakkında paydaş görüşlerinin açığa çıkarılması hedeflenmiştir.
Çanakkale kent merkezinde ortalama geceleme süresi düşük seviyededir. Son verilere göre ortalama geceleme süresi 1-2 gecedir. Söz konusu bu ortalamanın Çanakkale destinasyonu için yeterli olmadığı, paydaşlar tarafından ortaya konulmuştur. Çanakkale'ye gelen yabancı ve yerli ziyaretçilerin ağırlıkla Truva ören yeri ve Gelibolu Yarımadası Tarihi Milli Parkı'nı ziyaret ettikleri gözlenmektedir. Araştırma kapsamında görüşülen paydaşlar da bu tespiti yapmakta ve bir sorun olarak belirtmektedirler. Söz konusu sorunun çözümü için de ziyaretçilerin ilde kalış sürelerinin artırılmasına yönelik çalışmalar yapılması katılımcılar tarafından ön plana çıarılmaktadır. Çanakkale'nin sahip olduğu tarihi, doğal ve kültürel değerlerin yeterince tanıtılamadığ ve turizmde ticari değer olarak pazara sunulamadığı görüşü, yine katılımcılar arasında yaygın bir görüş olarak ortaya çıkmaktadır. Mevcut çekim merkezleri olan Gelibolu Yarımadası Tarihi Milli Parkı ve Truva'nın iyileştirilmesi başta olmak üzere, Kaz dağları, Assos, adalar ve Alexandrei Troas gibi çekiciliklerin de tanıtımının ve pazarlamasının yapılması ve alternatif turizme yönelinmesi fikirleri paydaşlarca ortaya konmaktadır.

Altyapı teması altında ulaşımdaki ve konaklama imkânlarındaki sıkıntılar, ağırlıkla üzerinde durulan konulardandır. Destinasyonun mevcut durumu incelendiğinde yoğunlukla bu konularda eleştirilerin olmasının kaçınılmaz olduğu görülmektedir. Çanakkale'ye ulaşım sadece karayolu ile sağlanabilmektedir. Bu durum Çanakkale'de turizm gelişimini olumsuz yönde etkileyen baş unsurlardan biri olarak öne çıkmaktadır. Çanakkale'ye ulaşım sadece karayolu aracılığıyla olmasına rağmen karayollarının da çok yeterli ve konforlu olduğunu söylemek zordur. Ulaşımda havayolu alternatifinin geliştirilmesi talep edilmektedir. Çanakkale'de konaklama imkânlarındaki yetersizlikler de paydaşlar tarafından ısrarla vurgulanmaktadır. Çanakkale kent merkezinde dört ve beş yıldızlı sadece birer tane otel bulunması, konaklama alternatiflerindeki sınırlılıkların açık bir göstergesidir. Marka otellerin gelmesi ile turizm sektöründe ürün ve hizmet kalitesinin artırılabileceği, paydaşlar arasında yaygın bir görüştür.

Çanakkale'de örgütlü çalışma konusunda paydaşların genel görüşü olumsuz yöndedir. Görüşülen yirmi dört paydaşın yirmisi örgütlenmenin 
olmadığını ifade etmiştir. Bir destinasyon yönetim örgütü oluşturulması durumunda, mevcut kamu yönetimi sistemi ve ildeki özel sektörün yapısı dikkate alındığında, destinasyon örgütlenmesinde valiliğin önderliğinde geniş kapsamlı bir katılım olması gerektiği, ifade edilen görüşlerdendir. Örgütün finansmanı konusunda da liderlikte olduğu gibi ağırlıklı görüş merkezi, yönetimden destek alınması yönündedir. Merkezi yönetimin dışında Güney Marmara Kalkınma Ajansı ve Avrupa Birliği fonları da finans sağlayabilecek kurumlar olarak ifade edilmiştir. Ancak gelişmiş destinasyonlardaki örnekler dikkate alındığında, özerk mali yapının oluşturulmasının ve turizmden elde edilen gelir veya harcama üzerinden fonlamanın yapılmasının sürdürülebilirlik ve özerklik açısından çok önemli olduğu, dikkat edilmesi gereken bir durumdur.

Çanakkale'yi sürdürülebilir bir destinasyon haline getirmek için paydaş görüşleri dikkate alınarak verilebilecek öneriler aşağıdaki gibidir:

- Sağlık ve kongre turizmi gibi alternatif turizm türleri geliştirilmeli.

- Çekiciliklerin çeşitlendirilmesi sağlanmalı, ulusal ve uluslararası tanıtım faaliyetlerinde bulunulmalı.

- Özellikle havayolu ve denizyolu olmak üzere her türlü ulaşım imkânı geliştirilmeli. Bu amaç doğrultusunda Çanakkale havaalanı işler hale getirilmeli ve yat limanı projesi hayata geçirilmelidir.

- Konaklama imkânlarının çoğaltılması amacıyla kente yatırımcı çekilmeli.

- Merkezi yönetimin liderliğinde geniş tabanlı bir destinasyon yönetim örgütü oluşturulmalı ve bu örgüt üzerinden bütüncül planlama ve politikalar belirlenmelidir.

Bu araştırma zaman kısıtı ve bazı imkânsızlıklar nedeniyle sadece kent merkezindeki ilgili kurum ve kişilerin ağırlıklı olduğu bir örneklem ile yapılmıştır. Bu nedenle araştırma sonuçlarının tüm ili kapsadığı söylenemez. Araştırmacılara tüm ili kapsayacak şekilde araştırmanın yapılması, adalardaki ve diğer ilçelerdeki belediyeler ve kaymakamlıklar başta olmak üzere il genelinde turizmle ilgili paydaşların da görüşmelere dahil edilmesi tavsiye edilmektedir.

\section{KAYNAKÇA}

Atay, L. ve Akyurt, H. (2007). Turizm Endüstrisinde Destinasyon Yönetimi, Sürdürülebilir Rekabet Avantaj Elde Etmede Turizm Sektörü: Sektörel Stratejiler ve Uygulamalar. Uluslararası Rekabet Araştırmaları Derneği Yayınları: 495-510.

Bornhorst, T., Sheehan, L. R ve Ritchie, B. J. R. (2009). Determinants of Tourism Success for DMOs \& Destinations: An Empiricial Examination of Stakeholders' Perspectives, Brs-Tm, 25: 1-42

Bramwell, B. ve Sharman, A. (1999). Collaboration in Local Tourism Policymaking, Annals of Tourism Research, 25 (2): 392-415.

Coltman, M. M. (1989). Tourism Marketing. New York: Van Nostrand Reinhold.

Cooper, C., Noel, S. ve Rodolfo, B. (2009). Network Position and Perceptions of Destination Stakeholder Importance, Anatolia: An International Journal of Tourism and Hospitality Research, 20 (1): 33-45.

Ersun, N. ve Kahraman A. (2011). Turizmde Destinasyon Seçimini Etkileyen Temel Unsurlar ve Pazarlama Stratejileri, Marmara Üniversitesi İktisadi ve İdari Bilimler Fakültesi Dergisi, 31 (2): 229-248.

http://media.unwto.org/en/press-release/2012-01-16/international-tourism-reach-one billion-2012, Erişim tarihi: 09.01.2013.

İçöz, O., Var, T. ve İlhan, İ. (2009). Turizm Politikası ve Planlaması. Ankara: Turhan Kitabevi.

Jamal, G. ve Getz, D. (1995). Collaboration Theory and Community Tourism Planning, Annals of Tourism Research, 22: 186-204.

Kozak, N., Akoğlan Kozak, M. ve Kozak, M. (2012). Genel Turizm. Ankara: Detay Yayıncılik.

Laws, E. (2002). Tourism Marketing. Londra: Continuum.

Morrison, A. M., Bruen, S. M. ve Anderson, D. J. (1998). Convention and Visitor Bureaus in the USA: A Profile of Bureaus, Bureau Executives and Budgets, Journal of Travel and Tourism Marketing, 7 (1): 1-19.

Olalı, H. (1990). Turizm Politikası ve Planlaması. İstanbul: Yön Ajans.

Özdemir, G. (2008). Destinasyon Pazarlaması. Ankara: Detay Yayincilik.

Patton, M. Q. (2002). Qualitative Research E Evaluation Methods. Londra: Sage Yayınları.

Presenza, A. (2006). The Performance of a Tourism Destination. Who Manages The Destination? Who Plays The Audit Role?, University of Molise-Department of Economics- Management and Social Science, 1-14.

Saftic, D., Ana, T. ve Minoslav, L. (2011). Stakeholder Approach in Tourism Management: Implication in Croatian Tourism, 30th International Conference on Organizational Science Development Future Organization, Portoroz, ss.1-8.

Semerciöz, F., Dönmez, D. ve Dursun, M. (2008). Relationships Between Destination Management Organizations and Destination Stakeholders a Research in Regions of Marmara, Aegean, Mediterranean in Turkey, Ticaret ve Turizm Ĕ̈itim Fakültesi Dergisi, 1: 87-101.

Sheehan, L. R ve Ritchie, B. J. R. (2005). Destination Stakeholders: Exploring Identity and Salience, Annals of Tourism Research, 32 (3): 711-734.

World Tourism Organization (2004). Survey of Destination Management Organisations Report. 
Yıldırım, A. ve Şimşek, H. (2011). Sosyal Bilimlerde Nitel Araștırma Yöntemleri. Ankara: Seçkin Yayınevi.

Yıldırım, A. ve Şimşek, H. (2000). Sosyal Bilimlerde Nitel Araştırma Yöntemleri. Ankara: Seçkin Yayınevi.

EK:

\section{PAYDAŞLAR IÇIN GÖRÜŞME FORMU}

- Mevcut Durumu Değerlendirme Soruları

1. Sizce sürdürülebilir destinasyon neyi ifade etmektedir? Destinasyonun sürdürülebilirliğini sağlamak için neler yapılması gerekir?

2. Çanakkale destinasyonunun sürdürülebilirlik açısından mevcut durumunu değerlendirir misiniz?

3. Çanakkale'de sürdürülebilirliği sağlamak adına paydaşlar arasında örgütlü çalışmalar yapılmakta midir?

4. Kurum olarak sürdürülebilir destinasyon yaratma sürecinde çalışmalarınız var mıdır?
- Muhtemel Örgütlenme ile İlgili Sorular

1. Sürdürülebilirliği sağlamak adına Çanakkale'de oluşturulacak bir Destinasyon Yönetim Örgütü'ne kimler dahil edilmelidir?

2. Oluşturulacak Destinasyon Yönetim Örgütü'nün liderliğini hangi kurum/kuruluş veya işletmeler yapmalıdır? Nedenini açıklayınız.

3. Oluşturulacak Destinasyon Yönetim Örgütü'nün finansal kaynakları nasıl sağlanmalıdır?

4. Örgütün sürdürülebilirliği sağlamaya yönelik faaliyetleri neler olmalıdır?

- Görüşülen Kişi

1. Adınız ve soyadınızı öğrenebilir miyim?

2. Görevinizi öğrenebilir miyim? 